\title{
Redox state of Archean kyanite/corundum eclogites and garnet pyroxenites from Bellsbank, South Africa
}

\author{
Heidi E. Höfer ${ }^{1 *}$, Gerhard P. Brey ${ }^{1}$, Qiao Shu ${ }^{2}$, Christian R.Heckel ${ }^{1}$, Prokopiy Vasilyev ${ }^{3}$ \\ ${ }^{1}$ Institut für Geowissenschaften, Goethe-Universität, Frankfurt, Germany, \\ hoefer@em.uni-frankfurt.de,brey@em.uni-frankfurt.de,heckchri@web.de \\ ${ }^{2}$ Dept. Earth Atmospheric Sciences, University of Alberta, Edmonton, Canada, qshu1@ualberta.ca \\ ${ }^{3}$ John de Laeter Centre, Curtin University, Perth, Australia, prokopiy.vasilyev@curtin.edu.au \\ *presenting author
}

\section{Introduction}

Oxygen fugacity determines the carbon species in eclogites and garnet pyroxenites and, with it, the transport properties of carbon and its role in the Earth's carbon cycle and as a host of diamond. The recently developed oxybarometers allow the estimation of oxygen fugacity of such rocks. One is based on the compositions of coexisting garnet (grt), clinopyroxene (cpx) and coesite (Stagno et al. 2015 ) and the other on the composition of garnet coexisting with kyanite (ky) and coesite (Vasilyev 2016). The oxygen fugacity of rare orthopyroxene-bearing garnet pyroxenites can be estimated with another oxybarometer based on coexisting garnet, orthopyroxene and olivine (Stagno et al. 2013).

\section{The investigated samples}

Aluminous eclogites containing kyanite and/or corundum (cor) from the Bellsbank diamond mine were interpreted as subducted troctolites and layered gabbros (Shu et al. 2016). They consist of grossular-rich garnets (orange brown), jadeite-rich clinopyroxenes (pale green) and pink corundum and/or blue kyanite (Fig. 1a). Garnet compositions are shown in Fig. 2 in a $\mathrm{CaO}_{-}-\mathrm{Cr}_{2} \mathrm{O}_{3}$ diagram.
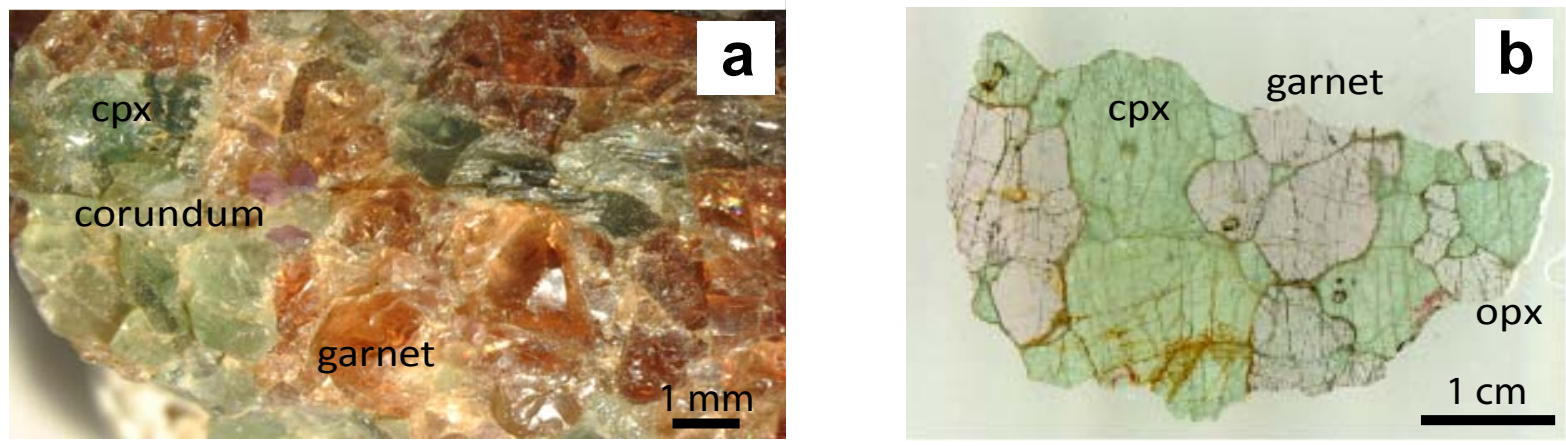

Figure 1: Corundum bearing eclogite xenolith from the Bellsbank diamond mine (a) and a polished thin section of an opx-bearing garnet pyroxenite (b)

These eclogites stem from depths between 150 and $200 \mathrm{~km}$ (Fig. 3). Low $\delta^{18} \mathrm{O}$ values below the mantle value indicate high temperature seafloor alteration of the precursor rocks. Depleted LREE patterns witness partial melting between 5 to $30 \%$ in the eclogite stability field after metamorphism. Very unradiogenic ${ }^{87} \mathrm{Sr} /{ }^{86} \mathrm{Sr}$ ratios as low as 0.70076 require a minimum age of $3 \mathrm{Ga}$ of these eclogites. Compared to cumulates of modern oceanic crust, the $\mathrm{V}$ and $\mathrm{Cr}$ systematics of the reconstructed bulk rocks indicate more reducing conditions during their original magma history. The application of partition coefficients obtained by Mallmann and O'Neill (2009) to these systematics yields a $\Delta \log \left(\mathrm{fO}_{2}\right)$ of -2 compared to the FMQ buffer for the eclogites and of zero for modern day oceanic crust cumulates.

A second type of high-pressure mafic xenoliths from Bellsbank are opx-bearing garnet-pyroxenites (Fig. 1b) that appear transitional to garnet peridotites. They consist of red, pyrope-rich garnets with $\mathrm{Cr}_{2} \mathrm{O}_{3}$ varying between 1.2 and $6 \mathrm{wt} \%$ (Fig. 2), green clinopyroxenes, greyish orthopyroxenes and occasionally olivine. They are from shallower depths between 110 and $140 \mathrm{~km}$ (Fig. 3). 


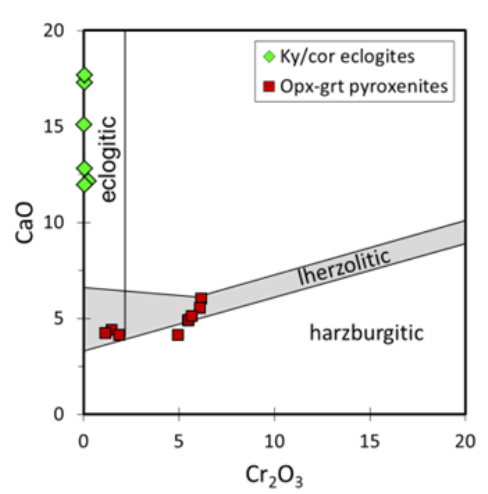

Figure 2: $\mathrm{CaO}$ versus $\mathrm{Cr}_{2} \mathrm{O}_{3}(\mathrm{wt} \%)$ in garnet

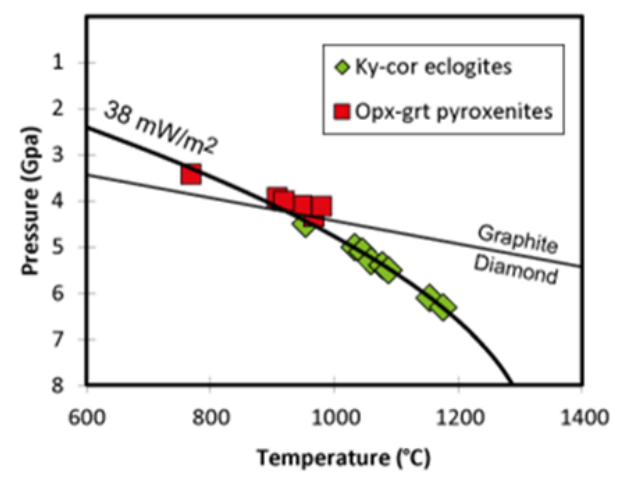

Figure 3: P,T-conditions of Bellsbank ky-cor eclogites (Shu et al. 2016) and opx-grt-pyroxenites. The latter were calculated with the methods of Brey \& Köhler (1990) and Harley (1984).

\section{Analytical technique for in situ ferric iron determination}

The oxidation state of Fe was determined in garnet by the flank method (Höfer and Brey 2007). The flank method uses the concomitant change of both the intensity and the wavelength of the soft FeL $\alpha$ and FeL $\beta$ emission lines in the electron microprobe to obtain the $\mathrm{Fe}^{3+} / \Sigma \mathrm{Fe}$ ratio (Fig. 4). The comparison with Mössbauer spectroscopy is very favourable with similar errors for both methods (Fig. 5). The error bars indicate that the "limit of detection" for both methods is about 0.02 .

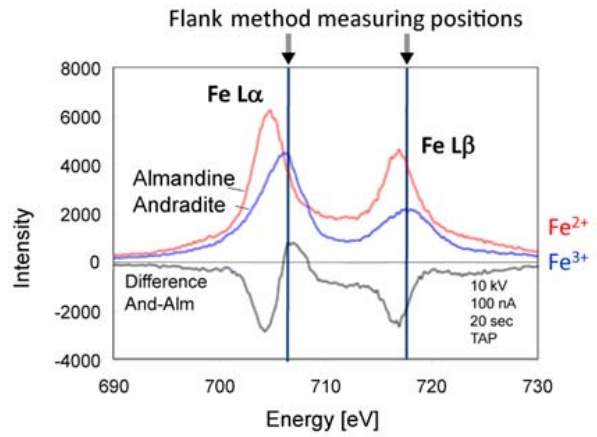

Figure 4: Fe L emission spectra of almandine and andradite and their difference spectrum.

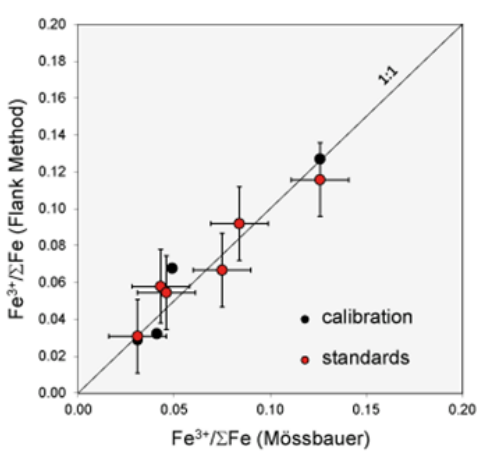

Figure 5: Calibration and comparison of the flank method with Mössbauer spectroscopy

\section{Results and discussion}

The $\mathrm{Fe}^{3+} / \Sigma \mathrm{Fe}$ values of the ky/cor-bearing eclogites are lower than 0.02 for 5 samples (Table 1 ). We have used the value of 0.02 to calculate oxygen fugacities for these garnets with very little $\mathrm{Fe}^{3+}$. The calculations were done with the oxybarometer of Vasilyev (2016) calibrated for kyanite bearing samples and the results are plotted in Fig. 6. The $\Delta \log \left(\mathrm{fO}_{2}\right)(\mathrm{FMQ})$ values are around -2 which are maximum values because of the reduced activity of $\mathrm{SiO}_{2}$ in our rocks (no coesite) and because the real $\mathrm{Fe}^{3+} / \Sigma \mathrm{Fe}$ values are lower than 0.02 . The assumption of a $\mathrm{SiO}_{2}$ activity of 0.5 lowers the calculated oxygen fugacity by about $0.2 \log$ units.

$\begin{array}{lcccccccc}\text { Ky/cor eclogite } & \text { BE1 } & \text { BE6 } & \text { BE11 } & \text { BE13 } & \text { BBm } & \text { BBs } & \text { BBu } & \text { BBw } \\ \mathrm{Fe}^{3+} / \Sigma \mathrm{Fe} & 0.023 & 0.024 & 0.034 & 0.008 & 0.009 & 0.009 & 0.007 & 0.009 \\ \text { Opx-grt-pyroxenite } & 60 \mathrm{BB} & 61 \mathrm{BB} & 62 \mathrm{BB} & 63 \mathrm{BB} & 64 \mathrm{BB} & 65 \mathrm{BB} & & \\ \mathrm{Fe}^{3+} / \Sigma \mathrm{Fe} & 0.057 & 0.093 & 0.022 & 0.029 & 0.020 & 0.038 & & \end{array}$

Table 1: $\mathrm{Fe}^{3+} / \Sigma \mathrm{Fe}$ determined with the flank method 
We have applied the oxybarometer of Stagno et al. (2013) for peridotites to the opx-bearing grtpyroxenites which is applicable to samples with $\mathrm{Ca}$-poor and $\mathrm{Cr}$-rich garnets. The $\mathrm{Fe}^{3+} / \Sigma \mathrm{Fe}$ values of these garnets vary between 0.02 and 0.09 (Table 1) and the calculated $\Delta \log \left(\mathrm{fO}_{2}\right)(\mathrm{FMQ})$ values range between -1 and -4 (Fig. 6). They overlap with those of the ky/cor-bearing eclogites whereby the aluminous eclogites mainly fall into the diamond field and the grt-pyroxenites into the graphite field. Two eclogites from Roberts Victor (Stagno et al. 2015) also plot in the graphite field (Fig. 6). Both graphite and diamond bearing eclogites have been described from Bellsbank and Roberts Victor. It is noteworthy and important that the various versions of oxybarometers for different types of eclogites yield a congruent data set and share the same range of $\Delta \log \left(\mathrm{fO}_{2}\right)(\mathrm{FMQ})$ values derived from garnet peridotites in the Kaapvaal craton as shown in Fig. 6 (after Stagno et al. 2015).

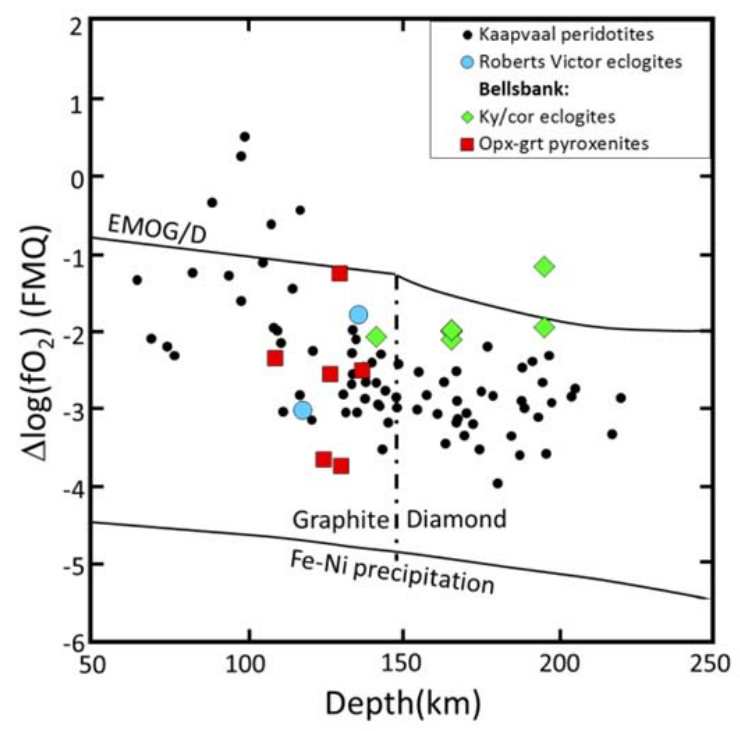

Figure 6: Variation of $\Delta \log \mathrm{fO}_{2}$ with depth for the studied xenoliths from Bellsbank plotted with Kaapvaal peridotites and Roberts Victor eclogites (Stagno et al. 2013, 2015). The position of the EMOG/D buffer relative to FMQ is given for comparison.

Why do the ky/cor-bearing eclogites contain hardly any $\mathrm{Fe}^{3+}$ ? Shu et al. (2016) had estimated a $\Delta \log \left(\mathrm{fO}_{2}\right)(\mathrm{FMQ})$ of -2 for the precursor magmas of these aluminous eclogites which overlaps with the maximum possible value from the present study. The eclogites have a history of high temperature sea floor alteration (low $\Delta^{18} \mathrm{O}$ values), subduction, high pressure metamorphism and partial melting. The earlier low-pressure processes potentially may or may not lead to oxidation at times before the great oxidation event but high-pressure partial melting leads to loss of $\mathrm{Fe}^{3+}$ which leaves a more reduced residuum. All these processes most likely led to a net result with lower $\mathrm{Fe}^{3+}$ and equilibration at lower oxygen fugacity than in the precursor rocks.

\section{References}

Höfer HE and Brey GP (2007) The iron oxidation state of garnet by electron microprobe: Its determination with the flank method combined with major-element analysis. Am Min 92: 873-885

Mallmann G, O’Neill HStC (2009) The crystal/melt partitioning of V during mantle melting as a function of oxygen fugacity compared with some other elements (Al, P, Ca, Sc, Ti, Cr, Fe, Ga, Y, $\mathrm{Zr}$ and $\mathrm{Nb}$ ). J Petrol 50(9):1765-1794

Shu Q, Brey GP, Hoefer H, Zhao Z, Pearson DH (2016) Kyanite/corundum eclogites from the Kaapvaal Craton: subducted troctolites and layered gabbros from the Mid- to Early Archean. Contrib Mineral Petrol (2016) 171: 11-24

Stagno V, Ojwang DO, McCammon CA, Frost DJ (2013) The oxidation state of the mantle and the extraction of carbon from the Earth's interior. Nature 493: 84-88

Stagno V, Frost DJ, McCammon CA, Mohseni H, Fei Y (2015) The oxygen fugacity at which graphite or diamond forms from carbonate-bearing melts in eclogitic rocks. Contrib Mineral Petrol (2015) 169:16

Vasilyev P (2016) The oxidation state of deeply subducted, altered oceanic crust: An experimental study and the evidence from natural samples. $\mathrm{PhD}$ thesis Canberra 